\title{
Genetic dissimilarity between biofortified lettuce genotypes for leaf carotenoid levels
}

\author{
Luciana Alves de Sousa ${ }^{*}$ (D), Gabriel Mascarenhas Maciel² (D), Fernando Cezar Juliatti'(D), \\ Igor Forigo Beloti' ${ }^{(D}$, Ana Carolina Silva Siquieroli²(D, Andressa Alves Clemente ${ }^{(D)}$
}

'Federal University of Uberlândia, Uberlândia, Brazil

${ }^{2}$ Federal University of Uberlândia, Monte Carmelo, Brazil

*Corresponding author, e-mail: ludavis1@yahoo.com.br

\begin{abstract}
Lettuce is the main leafy vegetable, presenting the highest consumption and economic importance in the world. In the recent decades, concerns about vitamin A deficiency have led Brazilian researchers to develop cultivars with higher levels of carotenoids provitamin A. Therefore the experiment aimed to verify the genetic dissimilarity of biofortified lettuce genotypes, investigating the correlation between agronomic characteristics and the potential for use to increase the carotenoid content in future breeding programs. Ninety one genotypes were evaluated, with 86 lettuce strains from hybridization between cultivars Pira 72 versus Uberlândia 10000 (rich in carotenoids) followed by three successive self-fertilizations and 5 commercial cultivars (Grand Rapids; UFU MC BIOFORT1; Pira 72; Uberlândia 10000 and Robusta).During the course of the trial, were evaluated characteristics as chlorophyll content of the leaves, plant diameter, stem diameter and the number of leaves per plant were counted. Genetic diversity was represented by a dendrogram that was obtained using the hierarchical method of UPGMA and the optimization method of Tocher. There is genetic divergence between the lettuce genotypes analyzed, and the carotenoid content character contributed most significantly to the divergence between the evaluated genotypes. The UFU215\#12 genotypes; UFU215\#14; UFU215\#2; UFU 215\# 1; UFU215\#4; UFU199\#3 and UFU 199\#2 have good agronomic characteristics and high levels of carotenoids, being promising to continue the biofortified lettuce breeding program, aiming to obtain new cultivars rich in carotenoids pro vitamin A.
\end{abstract}

Keywords: biofortification, genetic divergence, Lactuca sativa L., pro vitamin A

\section{Introduction}

Lettuce (Lactuca sativa L.) is the main leafy vegetable, presenting the highest consumption and economic importance in the world. Its consumption is mainly in the form of salads, being a food rich in vitamins (A, B1, B2, B5), calcium, potassium, sodium, phosphorus, iron, silicon, fluorine and magnesium, which may be involved in pro-active activities, vitamins and antioxidants, in addition to being sources of insoluble fibers (Silva et al., 2016). Lettuce is also a food that has a low caloric value, being an important ally for people seeking a healthier diet (Sala \& Costa, 2012).

Currently, several studies have shown its potential as a biofortified food, rich in carotenoids precursors of vitamin A (Silva \& Mura, 2010; Cassetari et al., 2015). This vitamin is found in foods of animal origin, whereas in vegetables, such as lettuce, precursor carotenoids of vitamin $A$ are provided, with $\beta$-carotene being the most important and abundant (Silva \& Mura, 2010). Deficiency of this vitamin is a serious public health problem worldwide, and may cause an increased risk of mortality, morbidity and blindness in children (Wiseman et al., 2017).In the recent decades, Brazilian researchers concerns about vitamin A deficiency, especially in less developed regions, have led to the development of cultivars with higher carotenoid content. One such cultivar is Uberlândia 10,000 , which has more than 10,000 international units (IU) of vitamin A in $100 \mathrm{~g}$ of fresh leaves (equivalent to 36 $\mathrm{mg}$ of $\beta$-carotene per $100 \mathrm{~g}$ of fresh leaves) (Sousa et al., 2007).

Food biofortification is linked to the development of basic crop cultivars with high levels of micronutrients, using conventional breeding practices alongside modern biotechnology practices (Garg et al., 2018). Also, the development of promising genotypes depends on the genetic variability available in germplasm banks 
(Lebeda et al., 2014). In this context, when crossing between divergent parents, it is possible to select higher plants in new segregating populations and, thus, develop new cultivars. The variability between these parents can be estimated by using measures of genetic dissimilarity (Treuren \& Hinton 2009; Azevedo et al., 2013). Despite all qualitative and commercial requirements, there are currently few lettuce cultivars rich in carotenoids.

The objective of this work was to verify the genetic dissimilarity of biofortified lettuce genotypes, investigating the correlation between agronomic characteristics and the potential for use to increase the carotenoid content in future breeding programs.

\section{Material and Methods}

The experiment was carried out between February and April 2016 in the city of Monte Carmelo (18 $42^{\prime} 43.19^{\prime \prime} \mathrm{S}$ and 47029'55.8'W, $873 \mathrm{~m}$ ). The minimum and maximum temperatures in the period in which the experiment was carried out were $15.17^{\circ} \mathrm{C}$ and $29.3^{\circ} \mathrm{C}$ respectively, with an average relative humidity of $77.8 \%$ and an average precipitation of $127 \mathrm{~mm}$. Ninety one genotypes were evaluated with 86 lettuce strains from hybridization between cultivars Pira 72 versus Uberlândia 10000 (rich in carotenoids) (Sousa et al., 2007) followed by three successive self-fertilizations carried out between 2013 and 2017. The genealogical breeding method was used. Five controls were used: the commercial cultivars Grand Rapids, Pira 72, Robusta, cv. UFU-Biofort (low carotenoid content) and the genotype Uberlândia 10000 (high content of carotenoids) (Sousa et al., 2007) totaling 91 treatments (Table 1).

The characterized genotypes are registered in the UFU's Biofortified Lettuce Genetic Improvement Program and the entire genealogy is stored in the "BG a BIOFORT" Software registered at INPI BR512019002403-6 (Maciel et al., 2019a) (Table 2).

Description and origin of the genotypes are shown in Table 2.

Sowing was carried out in expanded polystyrene trays of 200 cells, filled with commercial substrate based on coconut fiber. After sowing, the trays were kept in an arch type greenhouse, with dimensions of $5 \mathrm{~m} \times 6 \mathrm{~m}$ and $3.5 \mathrm{~m}$ high ceiling, covered with 150-micron transparent polyethylene film, additive against ultraviolet rays, and side curtains white anti-aphid screen.

Twenty five days after sowing, the seedlings were transplanted to the field, in beds of $1.25 \mathrm{~m}$ wide, previously prepared by a rotary harvester and fertilized, according to soil analysis that presented the following characteristics: clay texture, containing more than 50\% clay in its composition; $\mathrm{pH}$ in $\mathrm{CaCl}_{2}=4.9 ; \mathrm{MO}=3.9$ dag $\mathrm{kg}^{-1} ; \mathrm{Pmeh}=79.1 \mathrm{mg} \mathrm{dm}^{-3} ; \mathrm{K}=0.29 \mathrm{cmolc} \mathrm{dm}^{-3} ; \mathrm{Ca}=3.3$ cmolc dm-3 $\mathrm{Mg}=1.3 \mathrm{cmolc} \mathrm{dm}^{-3} ; \mathrm{H}+\mathrm{Al}=4.9 \mathrm{cmolc} \mathrm{dm}^{-3}$; $\mathrm{SB}=4.90 \mathrm{cmolc} \mathrm{dm}^{-3} ; \mathrm{T}=9.80 \mathrm{cmolc} \mathrm{dm} 3 ; \mathrm{V} \%=50$ and recommendations as required by the culture (Filgueira, 2013). Each plot consisted of 20 plants at a spacing of 25 $\mathrm{cm} \times 25 \mathrm{~cm}$. The six central plants were evaluated.

After 45 days of transplanting, the following evaluations were performed:

-Chlorophyll content: measured with the chlorophyll meter SPAD (Minolta SPAD-502 CFL1030 model), with an accuracy of \pm 1.0 SPAD unit, for values between 0.0 and 50.0 at normal temperature/humidity, on the median leaf of the plant, in the morning;

-Plant diameter $(\mathrm{cm})$ : using graduated ruler;

-Stem diameter ( $\mathrm{mm}$ ), using digital caliper and e -Number of leaves per plant.

The statistical design used was randomized blocks, with 91 treatments and three repetitions, using the following statistical model: Yij $=\mu+b j+t i+$ eij, where: Yij: observation of the i-th genotype in the j-th block; $\mu$ : fixed effect of the general average; ti: effect of the i-th genotype; bj: effect of the j-th block; eij: average experimental error.

The data obtained were submitted to analysis of variance by the $F$ test $(p=0.05)$. The means were compared using the Scott-Knott test ( $p=0.05)$. Then, multivariate analyzes were performed, with the objective of determining the genetic dissimilarity between the genotypes, obtaining the dissimilarity matrix by the generalized Mahalanobis distance $\left(D_{\mathrm{ii}^{\prime}}^{2}\right)$.

The genetic divergence was represented by a dendrogram, obtained by the hierarchical method Unweighted Pair-Group Method Using Arithmetic Averages (UPGMA) and by the method of tocher optimization. The validation of the grouping by the UPGMA method was determined by the cofenetic correlation coefficient (CCC), calculated by the Mantel test (1967). The relative contribution of quantitative characters was calculated according to Singh's criteria (1981).

To establish the cutoff point in the dendrogram, points of sudden change in level were used as a reference (Sudré et al., 2005; Resende, 2015). The correlation network procedure was done using the package "qgraph" (Epskamp et al., 2012). All data obtained were analyzed using the Genes v. 2015.5.0 (Cruz, 2013) and the Pearson's correlation network were performed using the software $R$ version 3.1.2 (R Core Team, 2015). 
Table 1. Codes of the 91 lettuce genotypes registered in the "BG a BIOFORT" Software at the Federal University of Uberlândia, Monte Carmelo, UFU, 2018.

\begin{tabular}{|c|c|c|c|}
\hline Code & Genotype & Code & Genotype \\
\hline 1 & UFU $117 \# 1$ & 47 & UFU 66\#7 \\
\hline 2 & UFU 120\#1 & 48 & UFU 66\#2 \\
\hline 3 & UFU 155\# 1 & 49 & UFU 202\# 1 \\
\hline 4 & UFU 71\# 1 & 50 & UFU 75\#3 \\
\hline 5 & UFU 122\#1 & 51 & UFU 75\#2 \\
\hline 6 & UFU 197\#3 & 52 & UFU 75\# 1 \\
\hline 7 & UFU 197\#2 & 53 & UFU 07\#2 \\
\hline 8 & UFU 197\#1 & 54 & UFU 07\# 1 \\
\hline 9 & UFU 143\#1 & 55 & UFU $114 \# 2$ \\
\hline 10 & UFU 140\# 1 & 56 & UFU $114 \# 1$ \\
\hline 11 & UFU $217 \# 6$ & 57 & UFU $215 \# 4$ \\
\hline 12 & UFU $217 \# 3$ & 58 & UFU 215\#3 \\
\hline 13 & UFU 09\#4 & 59 & UFU 215\#2 \\
\hline 14 & UFU 09\#3 & 60 & UFU $215 \# 1$ \\
\hline 15 & UFU 09\#2 & 61 & UFU $217 \# 5$ \\
\hline 16 & UFU 09\# 1 & 62 & UFU $217 \# 4$ \\
\hline 17 & UFU 66\# 1 & 63 & UFU $217 \# 2$ \\
\hline 18 & UFU 66\#5 & 64 & UFU 217\# 1 \\
\hline 19 & UFU 66\#6 & 65 & Robusta \\
\hline 20 & UFU 66\#4 & 66 & UFU 189\#3 \\
\hline 21 & UFU 86\#2 & 67 & UFU 189\#2 \\
\hline 22 & UFU 86\# 1 & 68 & UFU a $189 \# 1$ \\
\hline 23 & UFU 104\#6 & 69 & UFU 160\#2 \\
\hline 24 & UFU 104\#5 & 70 & UFU 160\# 1 \\
\hline 25 & UFU 190\# 1 & 71 & UFU 199\#6 \\
\hline 26 & UFU 107\# 1 & 72 & UFU 199\#5 \\
\hline 27 & UFU 124\#2 & 73 & UFU 199\#4 \\
\hline 28 & UFU 124\# 1 & 74 & UFU 199\#3 \\
\hline 29 & Grand Rapids & 75 & UFU 199\# 1 \\
\hline 30 & UFU MC BIOFORTI & 76 & UFU 199\#2 \\
\hline 31 & Pira 72 & 77 & UFU 169\#1 \\
\hline 32 & Uberlândia 10000 (Sousa et al., 2007) & 78 & UFU 206\#3 \\
\hline 33 & UFU $215 \# 12$ & 79 & UFU 206\#2 \\
\hline 34 & UFU 215\#11 & 80 & UFU 206\# 1 \\
\hline 35 & UFU 215\# 10 & 81 & UFU $215 \# 8$ \\
\hline 36 & UFU 215\#9 & 82 & UFU 215\#7 \\
\hline 37 & UFU 104\#4 & 83 & UFU 215\#6 \\
\hline 38 & UFU 104\#3 & 84 & UFU $215 \# 5$ \\
\hline 39 & UFU 104\#2 & 85 & UFU 106\#2 \\
\hline 40 & UFU 104\# 1 & 86 & UFU 106\# 1 \\
\hline 41 & UFU 184\#2 & 87 & UFU $210 \# 2$ \\
\hline 42 & UFU 184\# 1 & 88 & UFU 210\# 1 \\
\hline 43 & UFU 215\# 14 & 89 & UFU 125\# 1 \\
\hline 44 & UFU 215\#13 & 90 & UFU 125\#2 \\
\hline 45 & UFU 66\#3 & 91 & UFU 09\#5 \\
\hline 46 & UFU 66\#8 & & \\
\hline
\end{tabular}


Table 2. Origin and description of 91 lettuce genotypes registered in the "BG a BIOFORT" Software at the Federal University of Uberlândia, Monte Carmelo, UFU, 2018.

\begin{tabular}{|c|c|c|}
\hline Code & Description & Source \\
\hline 1 to 28 & Obtained after hybridization followed by three self-fertilizations. & F1 (Pira 72 x Uberlândia 10000) \\
\hline 29 & $\begin{array}{c}\text { Commercial cultivar of curly type and green leaves. It has resistance to M. incognita and } \\
\text { M. javanica (Gomes et al., 2000, 2002) and susceptibility to early flowering. }\end{array}$ & Agristar \\
\hline 30 & Commercial cultivar of curly type and green leaves. & UFU \\
\hline 31 & $\begin{array}{l}\text { Male parent (commercial curly-type cultivar, purple leaves, tolerant to early bolting, } \\
\text { tropicalized, resistance to mildew (Bremia lactucae) and LMV patotype II). }\end{array}$ & TSV Sementes \\
\hline 32 & $\begin{array}{l}\text { Female parent (Commercial cultivar of the smooth type, green leaves, rich in carotenoids, } \\
\text { tolerant to early bolting, susceptible to nematodes, to B. lactucae and LMV). }\end{array}$ & UFU \\
\hline 33 to 64 & Obtained after hybridization followed by three self-fertilizations. & F1 (Pira 72 x Uberlândia 10000) \\
\hline 65 & $\begin{array}{c}\text { Commercial cultivar of curly type and green leaves. Early cycle plant, tolerant to early } \\
\text { bolting and bacteriosis. }\end{array}$ & TSV Sementes \\
\hline 66 to 91 & Obtained after hybridization followed by three self-fertilizations. & F1 (Pira 72 x Uberlândia 10000) \\
\hline
\end{tabular}

\section{Results and Discussion}

There was a significant effect for all variables analyzed (SPAD index, plant diameter, stem diameter and number of leaves), indicating the existence of genetic variability between genotypes ( $F$ test, $5 \%$ probability). The genotypes UFU 215\#12; UFU 215\#14; UFU 215\#2; UFU
215\#1; UFU 215\#4; UFU 199\#3 and UFU 199\#2 stood out in terms of chlorophyll content in the leaves, presenting, respectively, $259.27 \%$; $269.95 \% ; 267.12 \% ; 268.32 \%$; $248.08 \%$; $261.34 \% ; 261.34 \% ; 249.96 \%$ more total chlorophyll than the cultivar Uberlândia 10,000, a cultivar considered rich in beta-carotene (Sousa et al., 2007) (Table 3).

Table 3. Mean of carotenoid content (SPAD index), plant diameter $(\mathrm{cm})$, stem diameter $(\mathrm{mm})$ and number of leaves per plant Monte Carmelo, UFU, 2018.

\begin{tabular}{|c|c|c|c|c|}
\hline Treatments & SPAD index & Plant diameter $(\mathrm{cm})$ & Stem diameter $(\mathrm{mm})$ & Number os leaves \\
\hline UFU $117 \# 1$ & $17.43 \mathrm{f}$ & $28.40 \mathrm{c}^{+}$ & $23.78 \mathrm{c}^{+}$ & $39.30 \mathrm{c}^{+}$ \\
\hline UFU 120\#1 & $18.41 \mathrm{f}$ & $21.60 \mathrm{f}^{+}$ & $10.20 \mathrm{f}^{*}$ & $26.10 e^{*+}$ \\
\hline UFU 155\#1 & $17.79 f$ & $27.10 \mathrm{~d}^{+}$ & $14.96 e^{*}$ & $28.30 \mathrm{~d}^{*+}$ \\
\hline UFU 71\# 1 & $28.19 \mathrm{~d}^{*+}$ & $26.60 \mathrm{~d}^{+}$ & $18.04 \mathrm{~d}^{+}$ & $30.10 \mathrm{~d}^{+}$ \\
\hline UFU 122\#1 & $12.54 \mathrm{~g}$ & $21.80 \mathrm{f}^{+}$ & $18.92 \mathrm{~d}^{+}$ & $25.10 \mathrm{e}^{*+}$ \\
\hline UFU 197\#3 & $23.54 e^{*+}$ & $21.55 \mathrm{f}^{+}$ & $19.67 \mathrm{~d}^{+}$ & $22.40 e^{*}$ \\
\hline UFU 197\#2 & $19.62 \mathrm{f}$ & $19.70 \mathrm{~g}^{*+}$ & $14.12 e^{*}$ & $27.60 \mathrm{~d}^{*+}$ \\
\hline UFU 197\#1 & $27.67 \mathrm{~d}^{*+}$ & $22.25 \mathrm{f}^{+}$ & $16.47 e^{*}$ & $29.90 \mathrm{~d}^{+}$ \\
\hline UFU 143\#1 & $23.39 \mathrm{e}^{*+}$ & $24.20 \mathrm{e}^{+}$ & $12.51 f^{*}$ & $23.60 \mathrm{e}^{*+}$ \\
\hline UFU 140\#1 & $22.36 e^{*+}$ & $22.90 \mathrm{f}^{+}$ & $19.02 \mathrm{~d}^{+}$ & $40.70 c^{+}$ \\
\hline UFU $217 \# 6$ & $25.47 \mathrm{~d}^{*+}$ & $27.90 \mathrm{c}^{+}$ & $17.69 \mathrm{~d}^{*}$ & $40.70 \mathrm{c}^{+}$ \\
\hline UFU $217 \# 3$ & $27.06 \mathrm{~d}^{*+}$ & $25.28 \mathrm{~d}^{+}$ & $16.89 e^{*}$ & $38.00 \mathrm{c}^{+}$ \\
\hline UFU 09\#4 & $23.01 e^{*+}$ & $28.15 \mathrm{c}^{+}$ & $20.34 \mathrm{~d}^{+}$ & $38.30 \mathrm{c}^{+}$ \\
\hline UFU 09\#3 & $22.01 \mathrm{e}^{+}$ & $21.65 \mathrm{f}^{+}$ & $21.87 c^{+}$ & $32.90 \mathrm{~d}^{+}$ \\
\hline UFU 09\#2 & $23.69 \mathrm{e}^{*+}$ & $21.30 \mathrm{f}^{+}$ & $16.79 e^{*}$ & $35.90 c^{+}$ \\
\hline UFU 09\# 1 & $21.97 e^{+}$ & $24.70 e^{+}$ & $24.78 c^{+}$ & $44.40 \mathrm{~b}^{+}$ \\
\hline UFU 66\# 1 & $23.72 e^{*+}$ & $30.45 c^{*+}$ & $22.30 c^{+}$ & $46.30 \mathrm{~b}^{+}$ \\
\hline UFU 66\#5 & $21.81 \mathrm{e}$ & $28.10 \mathrm{C}^{+}$ & $22.96 \mathrm{C}^{+}$ & $40.00 \mathrm{c}^{+}$ \\
\hline UFU 66\#6 & $26.72 \mathrm{~d}^{*+}$ & $21.70 \mathrm{f}^{+}$ & $20.80 \mathrm{~d}^{+}$ & $43.90 b^{+}$ \\
\hline UFU 66\#4 & $28.34 \mathrm{~d}^{*+}$ & $22.30 \mathrm{f}^{+}$ & $21.02 \mathrm{~d}^{+}$ & $34.90 \mathrm{c}^{+}$ \\
\hline UFU 86\#2 & $23.10 \mathrm{e}^{*+}$ & $39.85 \mathrm{a}^{*+}$ & $19.63 \mathrm{~d}^{+}$ & $35.80 c^{+}$ \\
\hline UFU 86\# 1 & $20.69 f$ & $30.10 \mathrm{c}^{+}$ & $17.41 \mathrm{~d}^{*}$ & $26.50 e^{*+}$ \\
\hline UFU 104\#6 & $24.54 e^{*+}$ & $21.55 \mathrm{f}^{+}$ & $23.78 c^{+}$ & $41.50 \mathrm{c}^{+}$ \\
\hline UFU 104\#5 & $27.01 \mathrm{~d}^{*+}$ & $22.30 \mathrm{f}^{+}$ & $24.08 c^{+}$ & $36.00 c^{+}$ \\
\hline UFU 190\# 1 & $22.92 e^{*+}$ & $29.00 \mathrm{c}^{+}$ & $21.77 c^{+}$ & $33.80 \mathrm{~d}^{+}$ \\
\hline UFU 107\#1 & $25.60 \mathrm{~d}^{*+}$ & $24.20 \mathrm{e}^{+}$ & $23.24 \mathrm{C}^{+}$ & $32.50 \mathrm{~d}^{+}$ \\
\hline UFU 124\#2 & $23.50 \mathrm{e}^{*+}$ & $23.30 \mathrm{e}^{+}$ & $22.29 \mathrm{c}^{+}$ & $36.00 c^{+}$ \\
\hline UFU 124\#1 & $23.32 e^{*+}$ & $23.80 e^{+}$ & $23.61 \mathrm{C}^{+}$ & $33.90 \mathrm{~d}^{+}$ \\
\hline Grand Rapids & $25.57 \mathrm{~d}^{*+}$ & $28.75 \mathrm{C}^{+}$ & $26.09 b^{+}$ & $39.40 \mathrm{c}^{+}$ \\
\hline UFU MC BIOFORTI & $24.14 \mathrm{e}^{*+}$ & $29.70 \mathrm{c}^{+}$ & $27.97 b^{+}$ & $31.70 \mathrm{~d}^{+}$ \\
\hline Pira 72 & $15.76 \mathrm{~g}$ & $14.80 \mathrm{~h}^{*}$ & $11.89 f^{*}$ & $13.90 f^{*}$ \\
\hline Uberlândia 10000 & $15.91 \mathrm{~g}$ & $25.45 \mathrm{~d}^{+}$ & $24.01 \mathrm{C}^{+}$ & $37.90 \mathrm{c}^{+}$ \\
\hline UFU $215 \# 12$ & $41.25 \mathrm{a}^{*+}$ & $24.90 \mathrm{e}^{+}$ & $20.95 \mathrm{~d}^{+}$ & $38.60 c^{+}$ \\
\hline UFU 215\# 11 & $38.05 b^{*+}$ & $22.80 \mathrm{f}^{+}$ & $19.32 \mathrm{~d}^{+}$ & $35.60 c^{+}$ \\
\hline UFU 215\# 10 & $35.48 b^{*+}$ & $18.60 \mathrm{~g}^{*}$ & $18.94 \mathrm{~d}^{+}$ & $28.80 \mathrm{~d}^{+}$ \\
\hline
\end{tabular}


Continue...

\begin{tabular}{|c|c|c|c|c|}
\hline UFU 215\#9 & $30.41 \mathrm{C}^{*+}$ & $23.40 \mathrm{e}^{+}$ & $19.96 \mathrm{~d}^{+}$ & $34.50 \mathrm{c}^{+}$ \\
\hline UFU 104\#4 & $28.96 \mathrm{~d}^{*+}$ & $25.95 \mathrm{~d}^{+}$ & $28.90 b^{+}$ & $31.80 \mathrm{~d}^{+}$ \\
\hline UFU 104\#3 & $26.21 \mathrm{~d}^{*+}$ & $23.55 \mathrm{e}^{+}$ & $24.30 \mathrm{c}^{+}$ & $46.80 b^{+}$ \\
\hline UFU 104\#2 & $31.14 \mathrm{C}^{*+}$ & $22.85 \mathrm{f}^{+}$ & $29.22 \mathrm{~b}^{+}$ & $35.90 \mathrm{c}^{+}$ \\
\hline UFU 104\#1 & $30.56 c^{*+}$ & $21.75 \mathrm{f}^{+}$ & $21.60 \mathrm{C}^{+}$ & $32.90 \mathrm{~d}^{+}$ \\
\hline UFU 184\#2 & $26.32 \mathrm{~d}^{*+}$ & $34.10 b^{*+}$ & $24.28 c^{+}$ & $36.40 \mathrm{c}^{+}$ \\
\hline UFU 184\# 1 & $29.82 c^{*+}$ & $35.80 \mathrm{~b}^{*+}$ & $26.73 b^{+}$ & $38.50 \mathrm{c}^{+}$ \\
\hline UFU 215\#14 & $42.95 \mathrm{a}^{*+}$ & $23.50 e^{+}$ & $19.65 \mathrm{~d}^{+}$ & $29.60 \mathrm{~d}^{+}$ \\
\hline UFU 215\#13 & $33.75 c^{*+}$ & $18.45 \mathrm{~g}^{*}$ & $17.71 d^{*}$ & $30.30 \mathrm{~d}^{+}$ \\
\hline UFU 66\#3 & $27.49 \mathrm{~d}^{*+}$ & $19.75 \mathrm{~g}^{*+}$ & $22.52 \mathrm{C}^{+}$ & $45.60 \mathrm{~b}^{+}$ \\
\hline UFU 66\#8 & $24.87 e^{*+}$ & $21.45 \mathrm{f}^{+}$ & $23.47 C^{+}$ & $40.40 c^{+}$ \\
\hline UFU 66\#7 & $27.26 \mathrm{~d}^{*+}$ & $21.40 \mathrm{f}^{+}$ & $25.84 b^{+}$ & $44.20 \mathrm{~b}^{+}$ \\
\hline UFU 66\#2 & $27.12 \mathrm{~d}^{*+}$ & $22.35 f^{+}$ & $19.99 \mathrm{~d}^{+}$ & $35.20 c^{+}$ \\
\hline UFU 202\# 1 & $25.06 \mathrm{~d}^{*+}$ & $23.55 e^{+}$ & $20.07 d^{+}$ & $29.00 \mathrm{~d}^{+}$ \\
\hline UFU 75\#3 & $30.46 C^{*+}$ & $25.70 \mathrm{~d}^{+}$ & $14.35 e^{*}$ & $21.50 e^{*}$ \\
\hline UFU 75\#2 & $32.27 c^{*+}$ & $23.85 \mathrm{e}^{+}$ & $16.02 e^{*}$ & $25.60 e^{*+}$ \\
\hline UFU 75\# 1 & $26.29 \mathrm{~d}^{*+}$ & $26.75 \mathrm{~d}^{+}$ & $23.13 C^{+}$ & $30.00 \mathrm{~d}^{+}$ \\
\hline UFU 07\#2 & $25.01 \mathrm{~d}^{*+}$ & $25.00 \mathrm{e}^{+}$ & $23.41 \mathrm{C}^{+}$ & $35.50 \mathrm{c}^{+}$ \\
\hline UFU 07\# 1 & $23.84 e^{*+}$ & $24.71 \mathrm{e}^{+}$ & $24.50 c^{+}$ & $29.20 \mathrm{~d}^{+}$ \\
\hline UFU $114 \# 2$ & $26.94 d^{*+}$ & $24.80 e^{+}$ & $19.98 \mathrm{~d}^{+}$ & $23.60 e^{*+}$ \\
\hline UFU $114 \# 1$ & $25.38 \mathrm{~d}^{*+}$ & $25.70 \mathrm{~d}^{+}$ & $22.10 \mathrm{C}^{+}$ & $24.90 e^{*+}$ \\
\hline UFU $215 \# 4$ & $39.47 \mathrm{a}^{*+}$ & $29.05 c^{+}$ & $24.56 c^{+}$ & $36.80 c^{+}$ \\
\hline UFU 215\#3 & $30.25 c^{*+}$ & $22.40 \mathrm{f}^{+}$ & $26.49 b^{+}$ & $37.50 c^{+}$ \\
\hline UFU 215\#2 & $42.50 \mathrm{a}^{*+}$ & $24.55 \mathrm{e}^{+}$ & $25.97 b^{+}$ & $37.70 \mathrm{c}^{+}$ \\
\hline UFU 215\# 1 & $42.69 \mathrm{a}^{*+}$ & $25.70 \mathrm{~d}^{+}$ & $23.01 \mathrm{C}^{+}$ & $37.30 \mathrm{c}^{+}$ \\
\hline UFU $217 \# 5$ & $32.70 c^{*+}$ & $26.40 \mathrm{~d}^{+}$ & $28.18 b^{+}$ & $52.10 \mathrm{a}^{*+}$ \\
\hline UFU $217 \# 4$ & $35.35 b^{*+}$ & $26.30 \mathrm{~d}^{+}$ & $24.63 c^{+}$ & $40.20 c^{+}$ \\
\hline UFU $217 \# 2$ & $30.45 c^{*+}$ & $23.40 \mathrm{e}^{+}$ & $18.43 \mathrm{~d}^{+}$ & $34.80 c^{+}$ \\
\hline UFU $217 \# 1$ & $33.86 c^{*+}$ & $25.30 \mathrm{~d}^{+}$ & $26.32 b^{+}$ & $52.00 \mathrm{a}^{*+}$ \\
\hline Robusta & $18.84 \mathrm{f}$ & $29.40 \mathrm{C}^{+}$ & $22.80 \mathrm{C}^{+}$ & $29.80 \mathrm{~d}^{+}$ \\
\hline UFU 189\#3 & $27.85 \mathrm{~d}^{*+}$ & $22.25 \mathrm{f}^{+}$ & $21.30 \mathrm{c}^{+}$ & $35.20 \mathrm{c}^{+}$ \\
\hline UFU 189\#2 & $31.77 c^{*+}$ & $24.15 \mathrm{e}^{+}$ & $24.62 c^{+}$ & $36.50 c^{+}$ \\
\hline UFU 189\# 1 & $27.87 \mathrm{~d}^{*+}$ & $26.60 \mathrm{~d}^{+}$ & $26.31 b^{+}$ & $46.90 b^{+}$ \\
\hline UFU 160\#2 & $24.02 e^{*+}$ & $26.55 \mathrm{~d}^{+}$ & $23.45 c^{+}$ & $32.00 \mathrm{~d}^{+}$ \\
\hline UFU 160\#1 & $23.95 e^{*+}$ & $24.00 e^{+}$ & $18.13 \mathrm{~d}^{+}$ & $35.20 c^{+}$ \\
\hline UFU 199\#6 & $37.95 b^{*+}$ & $30.05 c^{+}$ & $21.04 \mathrm{~d}^{+}$ & $39.60 \mathrm{C}^{+}$ \\
\hline UFU 199\#5 & $37.57 b^{*+}$ & $30.50 c^{*+}$ & $16.60 e^{*}$ & $35.20 c^{+}$ \\
\hline UFU 199\#4 & $30.19 c^{*+}$ & $25.80 \mathrm{~d}^{+}$ & $15.10 e^{*}$ & $26.60 e^{*+}$ \\
\hline UFU 199\#3 & $41.58 \mathrm{a}^{*+}$ & $26.70 \mathrm{~d}^{+}$ & $17.85 d^{*}$ & $33.50 \mathrm{~d}^{+}$ \\
\hline UFU 199\# 1 & $35.84 b^{*+}$ & $27.90 c^{+}$ & $19.64 \mathrm{~d}^{+}$ & $28.10 \mathrm{~d}^{*+}$ \\
\hline UFU 199\#2 & $39.77 \mathrm{a}^{*+}$ & $27.95 c^{+}$ & $18.94 \mathrm{~d}^{+}$ & $30.20 \mathrm{~d}^{+}$ \\
\hline UFU 169\# 1 & $21.45 \mathrm{e}$ & $28.75 C^{+}$ & $27.72 b^{+}$ & $36.40 c^{+}$ \\
\hline UFU 206\#3 & $25.59 \mathrm{~d}^{*+}$ & $23.70 e^{+}$ & $19.07 \mathrm{~d}^{+}$ & $29.60 \mathrm{~d}^{+}$ \\
\hline UFU $206 \# 2$ & $22.04 e^{*+}$ & $29.60 c^{+}$ & $21.32 c^{+}$ & $26.50 e^{*+}$ \\
\hline UFU 206\# 1 & $23.16 \mathrm{e}^{*+}$ & $25.65 \mathrm{~d}^{+}$ & $21.11 \mathrm{~d}^{+}$ & $24.80 e^{*+}$ \\
\hline UFU 215\#8 & $38.49 b^{*+}$ & $17.30 \mathrm{~g}^{*}$ & $21.92 c^{+}$ & $39.70 \mathrm{c}^{+}$ \\
\hline UFU 215\#7 & $35.91 b^{*+}$ & $21.05 \mathrm{f}^{+}$ & $22.44 \mathrm{C}^{+}$ & $32.00 \mathrm{~d}^{+}$ \\
\hline UFU 215\#6 & $36.57 b^{*+}$ & $14.55 \mathrm{~h}^{*}$ & $18.97 \mathrm{~d}^{+}$ & $23.20 e^{*}$ \\
\hline UFU 215\#5 & $36.09 b^{*+}$ & $18.50 \mathrm{~g}^{*}$ & $19.53 \mathrm{~d}^{+}$ & $31.70 \mathrm{~d}^{+}$ \\
\hline UFU 106\#2 & $33.41 c^{*+}$ & $22.45 \mathrm{f}^{+}$ & $24.25 c^{+}$ & $34.90 c^{+}$ \\
\hline UFU 106\# 1 & $27.54 \mathrm{~d}^{*+}$ & $32.75 b^{*+}$ & $25.72 b^{+}$ & $53.20 a^{*+}$ \\
\hline UFU $210 \# 2$ & $27.04 \mathrm{~d}^{*+}$ & $21.75 \mathrm{f}^{+}$ & $24.37 c^{+}$ & $43.30 b^{+}$ \\
\hline UFU $210 \# 1$ & $23.06 e^{*+}$ & $28.45 \mathrm{C}^{+}$ & $33.30 a^{*+}$ & $44.10 b^{+}$ \\
\hline UFU 125\# 1 & $26.42 \mathrm{~d}^{*+}$ & $18.90 \mathrm{~g}^{*}$ & $24.03 c^{+}$ & $26.40 e^{*+}$ \\
\hline UFU 125\#2 & $22.07 e^{*+}$ & $15.50 \mathrm{~h}^{*}$ & $22.19 \mathrm{C}^{+}$ & $28.10 \mathrm{~d}^{*+}$ \\
\hline UFU 09\#5 & $26.85 \mathrm{~d}^{*+}$ & $19.95 \mathrm{~g}^{*+}$ & $23.04 \mathrm{C}^{+}$ & $33.00 \mathrm{~d}^{+}$ \\
\hline
\end{tabular}


Sousa et al. (2019) evaluating SPAD index in 49 lettuce genotypes, from the same breeding program (generation F6), found six superior genotypes than the cultivar Uberlândia 10.000, presenting 209.29\%; 224.74\%; $223.42 \% ; 234.37 \% ; 209.15 \%$ and $226.54 \%$ more in terms os chlorophyll content. It is an advance of two generations in relation to the present work, which shows an increase in the content of carotenoids. Thus, it can be said that the genotypes in question have high values of carotenoids (SPAD index), which can be selected to continue the lettuce genetic improvement program aiming the biofortification with carotenoids, enabling the obtaining of promising cultivars for this characteristic.

Several studies show the efficiency of the SPAD index as an alternative to measure levels of chlorophyll in leaves (Klooster et al., 2012). In addition, the chlorophyll content is highly related to the concentration of carotenoids in lettuce, suggesting that the SPAD index can be used as an indirect indicator of the content of these pigments in these plants (Cassetari et al., 2015).

Consumers tend to purchase large heads of lettuce, that is, with the largest possible plant diameter, making this characteristic of great value for the breeding program (Sousa et al., 2019). In the present work, regarding the plant diameter (cm), UFU 86 \# 2 genotype stood out with an average value of $39.85 \mathrm{~cm}$, being statistically superior to the cultivars UFU MC Biofort1, Robusta, Grand Rapids, Uberlândia 10000 and Pira 72 that presented an average diameter of $29.70 \mathrm{~cm} ; 29.40 \mathrm{~cm} ; 28.75 \mathrm{~cm} ; 25.45$ $\mathrm{cm}$ and $14.80 \mathrm{~cm}$, respectively (Table 3 ).

Sousa et al. (2019) found high values of plant diameter $(\mathrm{cm})$ for the genotypes Crespa 117\#1\#3-E $(39.46 \mathrm{~cm})$, Crespa 75\#1\#1-E $(35.71 \mathrm{~cm})$ and Crespa 86\#2\#1-E (36.92 cm), being also statistically superior to the cultivars Pira 72 (Belíssima), Uberlândia 10.000 and Robusta. Maciel et al. (2019b), evaluating 31 genotypes of lettuce, from the same breeding program (generation F7) found 22 lines with plant diameter, statistically superior to cultivating Pira 72 (Belíssima).

Regarding the stem diameter, the genotype UFU210\# 1 was statistically superior to the five commercial cultivars evaluated, with an average diameter of $33.30 \mathrm{~mm}$ (Table 3). In a study by Sousa et al. (2019) the genotypes that showed the largest stem diameters ranged from 22.62 $\mathrm{mm}$ to $31.37 \mathrm{~mm}$, not differing statistically from the cultivar Uberlândia 10000 and differing from the cultivar Robusta. However, Maciel et al. (2019b), found no statistical difference for this characteristic in the evaluated lettuce genotypes.

It is important to point out that stem diameter is correlated with leaf area, i.e., with the transpiration rate, because the greater stem diameter is correlated with a greater vascularization of the plant and, consequently, larger leaf area as well and this correlation can be observed in the study of Monteiro Filho et al. (2017), in which the mineral solutions that promoted greater stem diameter also promoted larger leaf area. Other factors can afect the stem diameter such as the growing season, the lettuce cultivar, salinity stress (Ekinci et al., 2012; Sublet et al., 2018).

Besides that, stem diameter is of major importance in lettuce, especially for fast food industry, because, as leaves are manually separated for later slicing, the thicker the stem the faster it is separated, increasing industrial output (Targino et al., 2019).

In the characteristic number of leaves, the genotypes UFU217\#5, UFU217\#1 and UFU106\#1 presented, respectively, an average of $52.1 ; 52.0$ and 53.2 leaves, being superior to the others, including commercial cultivars, which presented 39.4 (Grand Rapids), 37.9 (Uberlândia 10000), 31.7 (UFU MC Biofort 1), 29.8 (Robusta) and 13.9 (Pira 72) (Table 3). Sousa et al. (2019) for the same trait found seven superior genotypes in relation to the Robusta cultivar, however they did not differ from the control Uberlândia 10000. Maciel et al. (2019b) found thirteen genotypes that have more leaves in relation to cultivar Pira 72 (Belíssima). Diamante et al. (2013) reported the importance of the characteristic number of leaves in growing lettuce, being relevant for the producer, both for indicating adaptation of the genetic material to the environment, as for the commercialization.

Among the evaluated genotypes, 12 did not differ by the Dunnet test $(P=0.05)$ of the cultivar Uberlândia 10000 for carotenoid content, among them, the cultivar Pira 72; seventy-three genotypes did not differ for plant diameter and stem diameter. The cultivars Grand Rapids, UFU MC Biofortl and Robusta did not differ from Uberlândia 10000 for plant diameter, stem diameter and number of leaves (Table 3).

Regarding the cultivar Pira 72, 10 genotypes did not differ for carotenoid content, among them the cultivars Robusta and Uberlândia 10000; seven for plant diameter, fifteen for stem diameter and two for number of leaves (Table 3). It can be inferred that the genotypes are promising, as they present similar agronomic performance or in most cases superior to the commercial cultivars evaluated.

The groups formed by the UPGMA hierarchical method (Figure 1) had a cofenetic correlation coefficient of $63 \%$. Eleven groups were formed and the groups were 
separated by delimiting a $32 \%$ cut-off line, established at the site of the abrupt change in the branches present in the dendrogram (Cruz et al., 2012).

The formation of these groups demonstrates wide genetic variability. Group I, with 43 genotypes; group II, with 13 genotypes including the cultivars: Grand Rapids, UFU MC Biofort, Uberlândia 10000 and Robusta; group
III with two genotypes; group IV with three genotypes; group $V$ with the genotype UFU2010 \# 1 (88); group VI with 11 genotypes; group VII with three genotypes, group VIII with seven genotypes, group IX with three genotypes, group $X$ with four genotypes and group XI with the cultivar Pira 72 (31) (Figure 1).

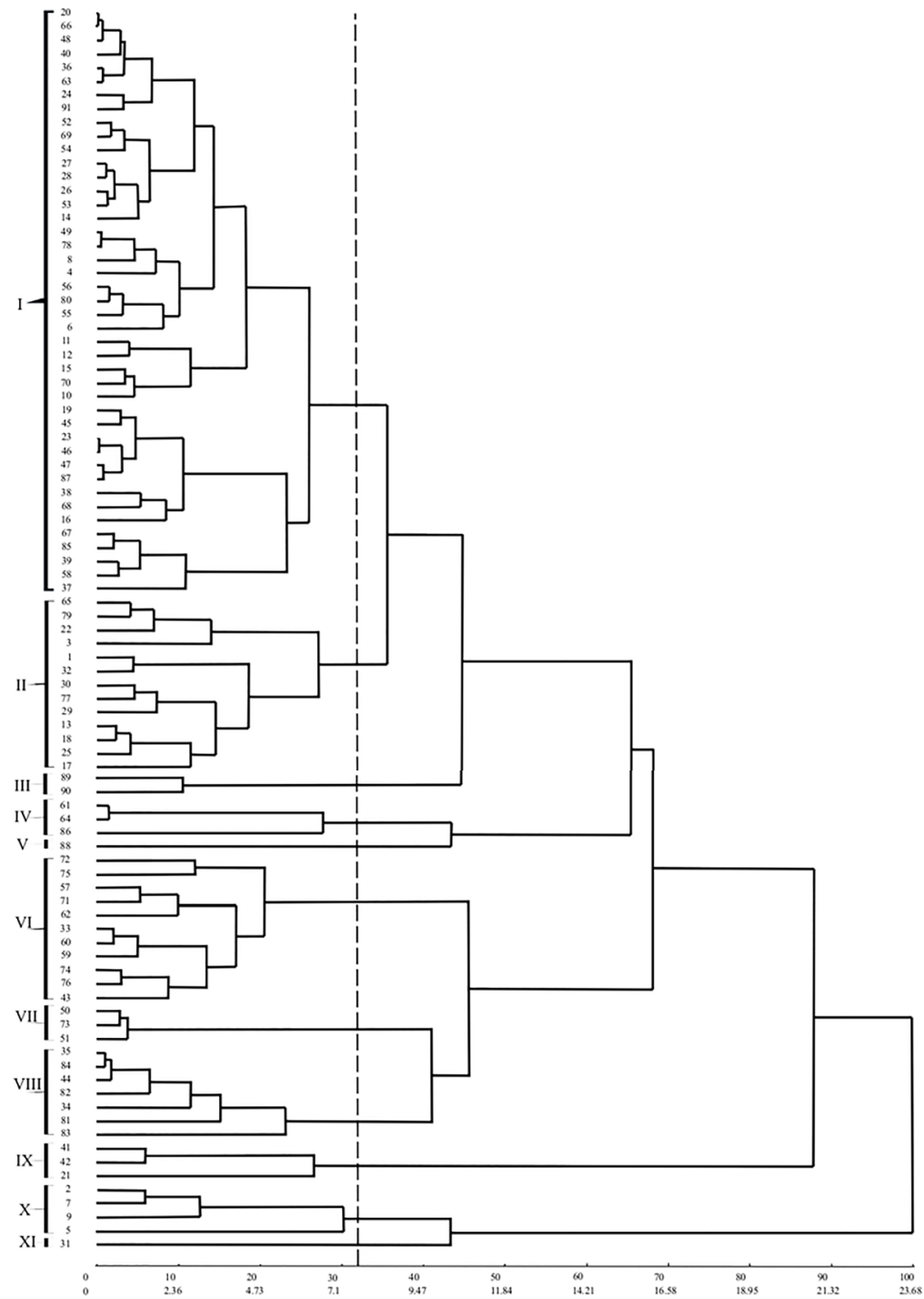

Figure 1. Dendrogram of the genetic divergence between 91 lettuce genotypes by the Hierarchical Method of medium link between "UPGMA" group obtained by the generalized Mahalanobis distance $\left(D_{i i}^{2}\right)$.

Maciel et al. (2019b) evaluating thirty-one red lettuce genotypes, aiming to determine the genetic dissimilarity by the UPGMA method, found seven groups (20\% cut-off line), and the cultivar Pira 72 (Belíssima) formed a group of just two genotypes. Sousa et al. (2019), evaluating 49 genotypes of biofortified lettuce with resistance to root-knot nematodes (Meloidogyne spp.) found by the UPGMA method (30\% cut-off line) four distinct groups, being the cultivars Pira 72 and Uberlândia 10,000 belonged to the same group formed by 21 genotypes; the Robusta cultivar was grouped in another group with ten genotypes.

By Tocher's optimization method, eleven groups were obtained, with emphasis on group (I), with 49 genotypes including the cultivar Grand Rapids (29); followed by group (III), with eleven genotypes; group (II), with ten genotypes; group (IV) with seven genotypes, including the cultivar Robusta; group (V) with five genotypes including the cultivars UFU MC Biofort-1 (30) and Uberlândia 10000 (32); group (VI) with three genotypes; group VII with two genotypes; and groups (VIII, IX, X and XI) each with only one genotype. 
As observed in the UPGMA clustering method, the UFU distinct groups with only one genotype each (Table 4).

$210 \# 1$ (88) genotype and the cultivar Pira 72 (31) formed

Table 4. Representation of the cluster generated by the Tocher Optimization Method based on Mahalanobis distance, estimated from four agronomic characteristics, analyzed in 91 lettuce genotypes.

\begin{tabular}{cc}
\hline Group & Code \\
\hline I & $20 ; 66 ; 48 ; 36 ; 40 ; 63 ; 24 ; 26 ; 91 ; 53 ; 27 ; 78 ; 49 ; 28 ; 70 ; 14 ; 46 ; 8 ; 15 ; 23 ; 69 ; 54 ; 52 ; 10 ; 12 ; 4 ; 19 ; 87 ; 67 ; 58 ;$ \\
II & $13 ; 56 ; 55 ; 80 ; 25 ; 18 ; 11 ; 29 ; 16 ; 38 ; 47 ; 85 ; 37 ; 45 ; 39 ; 68 ; 89 ; 77 ; 6$ \\
III & $35 ; 84 ; 44 ; 82 ; 34 ; 81 ; 83 ; 43 ; 51 ; 33$ \\
IV & $61 ; 64 ; 62 ; 57 ; 71 ; 60 ; 59 ; 74 ; 76 ; 75 ; 72$ \\
V & $50 ; 73 ; 9 ; 22 ; 79 ; 3 ; 65$ \\
VI & $1 ; 32 ; 17 ; 30 ; 41$ \\
VII & $2 ; 7 ; 5$ \\
VIII & $42 ; 86$ \\
IX & 88 \\
X & 21 \\
XI & 90 \\
\hline
\end{tabular}

Sousa et al. (2019) evaluating the characteristics of SPAD, leaf temperature, plant diameter, stem diameter, number of leaves and fresh mass in 49 lettuce genotypes from the same breeding program (F6 generation), using the method of grouping of Tocher, found the cultivars Robusta and Uberlândia 10000 belonging to the same group; the cultivar Pira 72 was also grouped individually. In a study by Jacinto et al. (2019), evaluating the same characteristics evaluated in the present work in 19 minilettuce genotypes, from the same breeding program, two groups were formed by the Tocher method, in which the cultivar Uberlândia 10000 was grouped with 16 genotypes in the group (I) and the cultivar Pira 72 in group (II) which had only two genotypes.

Although the number of clusters by the Tocher optimization method and the UPGMA hierarchical method are the same (eleven groups), there are visible differences in the number of genotypes per group (Figure 1 and Table 4). This disagreement between multivariate methods was also observed by authors who worked with the same species (Sousa et al., 2019; Jacinto et al., 2019).

The use of multivariate analysis for yield variables allows a more explicit visualization of genetic dissimilarity of cultivars and helps the crosses in breeding programs. The use of different methods allows for greater discriminating power, eliminating those difficult to measure variables and those that contribute little towards explaining variation. Among these methods, hierarchical and optimization methods are employed on a large scale by plant breeders (Bertan et al., 2006; Araujo et al., 2016).

The greatest relative contribution was related to the SAPD index in the discrimination of the evaluated genotypes (39.91\%), followed by the characteristics plant diameter $(26.54 \%)$, number of leaves (19.45\%) and stem diameter (14.08\%) (Table 5). This demonstrates the great importance of the evaluation of the SPAD index, in the field, for future improvement programs of biofortified lettuces. Corroborating this fact, Sousa et al. (2019) and Maciel et al. (2019b), found values of $24.84 \%$ and $60.31 \%$, respectively, for the same index, being the largest relative contribution among the characteristics evaluated.

Table 5. Relative contribution of the quantitative characteristics in the genetic diversity of the 91 evaluated lettuce genotypes, according to Singh (1981).

\begin{tabular}{ccc}
\hline Characteristics & S.j & S.j (\%) \\
\hline SPAD & 20816.63 & 39.91 \\
Plant diameter & 13842.58 & 26.54 \\
Stem diameter & 7344.20 & 14.08 \\
Number of leaves & 10144.75 & 19.45 \\
\hline
\end{tabular}

The network constructed with correlations of the evaluated characteristics is shown in Figure 2.

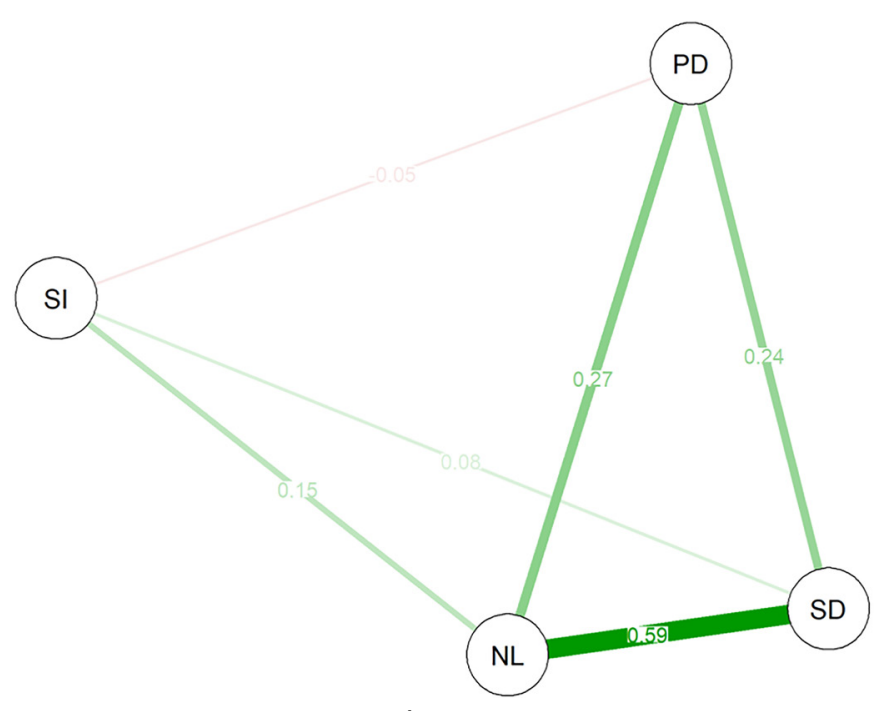

Figure 2. Network of Pearson's correlations of lettuce genotype characteristics. SI: SPAD index; PD: Plant diameter; SD: Stem diameter; NL: Number of leaves. The red lines represent negative correlations and the green positive ones. The line thickness is proportional to the magnitude of the correlation. 
Positive correlations were found between most of the agronomic characteristics, a circumstance favorable to the improvement of lettuce (Azevedo et al., 2014). The number of leaves showed a positive correlation with stem diameter (0.59), plant diameter (0.24) and SPAD index (0.15). Plant diameter showed a positive correlation with stem diameter (0.24) and a negative one with SPAD index (-0.05). SPAD index showed a positive correlation with stem diameter (0.08). Thus, it is noticed that the levels of carotenoid (highly correlated with the SPAD index) (Cassetari et al., 2015), are little influenced by the characteristics of leaf number, stem diameter and plant diameter. Azevedo et al. (2014) evaluating 11 lettuce cultivars also found a positive genotypic correlation between number of leaves and head diameter (0.66).

\section{Conclusions}

There is genetic divergence between the lettuce genotypes analyzed, and the carotenoid content character contributed most significantly to the divergence between the evaluated genotypes. The UFU215\#12 genotypes; UFU215\#14; UFU215\#2; UFU 215\# 1; UFU215\#4; UFU199\#3 and UFU199\#2 have good agronomic characteristics and high levels of carotenoids, being promising to continue the biofortified lettuce breeding program, aiming to obtain new cultivars rich in carotenoids pro vitamin A.

\section{References}

Araujo, J.C., Telhado, S.F.P., Sakai, R.H., Ledo, C.A.S., Melo, P.CT. 2016. Univariate and multivariate procedures for agronomic evaluation of organically grown tomato cultivars. Horticultura Brasileira 34: 374-380.

Azevedo, A.M., Andrade Júnior, V.C., Oliveira, C.M. Fernandes, J.S.C., Pedrosa, C.E., Dornas, M.F.S., Castro, B.M.C. 2013. Seleção de genótipos de alface para cultivo protegido: divergência genética e importância de caracteres. Horticultura Brasileira 31: 260-265.

Azevedo, A.M., Andrade Júnior, V.C., Castro, B.M.C., Oliveira, C.M., Pedrosa, C.E., Dornas, M.F.S., Valadares, N.R. 2014. Parâmetros genéticos e análise de trilha para o florescimento precoce e características agronômicas da alface. Pesquisa Agropecuária Brasileira 49: 118-124.

Bertan, I., Carvalho, F.I.F., Oliveira, A.C., Vieira, E.A., Hartwig, I., Silva, J.A.G., Shimidt, D.AM., Valério, I.P. Busato, C.C., Ribeiro, G. 2006. Comparação de métodos de agrupamento na representação da distância morfológica entre genótipos de trigo. Revista Brasileira de Agrociência 12: 279-286.

Cassetari, L.S., Gomes, M.S., Santos, D.C., Santiago, W.D., Andrade, J., Guimarães, A.C., Souza, J.A., Cardoso, M.G., Maluf, W.R., Gomes, L.A. 2015. $\beta$-Carotene and chlorophyll levels in cultivars and breeding lines of lettuce. Acta Horticulturae 1083: 469-474.
Cruz, C.D., Regazzi, A.J., Carneiro, P.C.S. 2012. Modelos biométricos aplicados ao melhoramento genético. Editora da UFV, Viçosa, Brazil. 514 p.

Cruz, C.D. 2013. GENES: a software package for analysis in experimental statistics and quantitative genetics. Acta Scientiarum. Agronomy 35: 271-276.

Diamante, M.S., Seabra Júnior, S., Inagaki, A.M., Silva, M.B., Dallacort, R. 2013. Production and resistance to bolting of loose-leaf lettuce grown in different environments. Revista Ciência Agronomica 44: 133-140.

Ekinci, M., Yildirim, E., Dursun, A., Turan, M. 2012. Mitigation of salt stress in lettuce (Lactuca sativa I. var. crispa) by seed and foliar 24-epibrassinolide treatments. HortScience 47: 631-636.

D., Borsboom, D. 2012. Qgraph: network visualizations of relationships in psychometric data. Journal of Statistical Software 48: 1-18.

Filgueira, F.A.R. 2013. Novo manual de olericultura: agrotecnologia moderna na produção e comercialização de hortaliças. Editora da UFV, Viçosa, Brazil. 412 p.

Garg, M., Sharma, N., Sharma, S., Kapoor, P., Kumar, A., Chunduri, V., Arora, P. 2018. Biofortified crops generated by breeding, agronomy, and transgenic approaches are improving lives of millions of people around the world. Frontiers in Nutrition 5: 12-45.

Gomes, L.A.A., Maluf, W.R., Azevedo, S.M., Freitas, J.A., Licursi, V. 2002. Reação de cultivares de alface a infecção por Meloidogyne javanica. Horticultura Brasileira 14: 99103.

Gomes, L.A.A., Maluf, W.R., Campos, V.P. 2000. Inherintance of the resistance reaction of the lettuce cultivar 'Grand Rapids' to the southern root-knot nematode Meloidogyne incognita (Kofoid \& White) Chitwood. Euphytica 114: 37-46.

Jacinto, A.C.P., Silveira, A.J., Castoldi, R., Maciel, G.M., Siquieroli, A.C.S., Mendonça, T.F.N., Souza, A.P., Marin, M.V., Braz, L.T. 2019. Genetic diversity, agronomic potential and reaction to downy mildew in genotypes of biofortified mini lettuce. Genetics and Molecular Research 18.

Klooster, W.S., Creg, B.M., Fernandez, R.T., Nzokou, P. 2012. Growth and physiology of deciduous shade trees in response to controlled-release fertilizer. Scientia Horticulturae 135: 71-79.

Lebeda A., Kř́stková, E., Kitner, M., Mieslerová, B., Jemelková, M., Pink, D.A.C. 2014. Wild Lactuca species, their genetic diversity, resistance to diseases and pests, and exploitation in lettuce breeding. European Journal of Plant Pathology 138: 597-640.

Maciel, G.M., Siquieroli, A.C.S., Gallis, R.B.A., Pereira, L.M., Sales, V.F. 2019a. BG a BIOFORT. 2019a. Patent: Computer program. Registration number: BR512019002403-6, registration date: 10/29/2019, title: "BG a BIOFORT", Registration institution: Universidade Federal de 
Uberlândia, Uberlândia, Brazil.

Maciel, G.M., Gallis, R.B.A., Barbosa, R.L., Pereira, L.M., Siquieroli, A.C.S., Peixoto, J.V.M. 2019b. Image phenotyping of inbred red lettuce lines with genetic diversity regarding carotenoid levels. International Journal of Applyed Earth Observation and Geoinformation 81: 154-160.

Mantel, N. 1967. The detection of disease clustering and a generalized regression approach. Cancer Research 27: 209-220.

Monteiro Filho, A.F., Azevedo, M.R.Q.A., Azevedo, C.A.V., Fernandes, J.D., Silva, C.R., Silva, Y.S. 2017. Growth of hydroponic lettuce with optimized mineral and organomineral nutrient solutions. Revista Brasileira de Engenharia Agrícola e Ambiental 21: 191-196.

$\mathrm{R}$ Development Core Team. R: A language and environment for statistical computing. 2015. https://www. rproject.org/ < Access on 01 Jan. 2020>

Resende, M.D.V. 2015. Genética quantitativa e de populações. Produção Independente, Viçosa, Brazil. 463 p.

Sala, F.C., Costa, C.P. 2012. Retrospectiva e tendência da alfacicultura brasileira. Horticultura Brasileira 30: 187194

Silva, S.M.C., Mura, J.D.P. 2010. Tratado de alimentação, nutrição e dietoterapia. Roca, São Paulo, Brazil. 1256 p.

Silva, A.A.V., Costa, A.F.M., Freitas, R.M.S., Santos, M.B.S.V., Lourenço, A.L.N., Malta, A.S., Noé, P.V.R. 2016. Qualidade parasitológica e condições higiênico-sanitárias de sururu (Mytella charruana) e alface (Lactuca sativa) comercializados em um mercado público de Maceió-AL. Journal of Basic and Applied Pharmaceutical Sciencies 36: $525-529$

Singh, D. 1981. The relative importance of characters affecting genetic divergence. The Indian Journal of Genetic and Plant Breeding 41: 237-245.

Sousa, C.S., Bonetti, A.M., Goulart Filho, L.R., Machado, J.R.A., Londe, L.N., Baffi, M.A., Ramos, R.G., Vieira, C.U., Kerr, W.E. 2007. Divergência genética entre genótipos de alface por meio de marcadores AFLP. Bragantia 66: 1116.

Sousa, L.A., Jacinto, A.C.P., Silveira, A.J., Castoldi, R., Maciel, G.M., Beloti, I.F. 2019. Agronomic potential of biofortified crisphead lettuce (Lactuca sativa) and its reaction to Root-knot nematodes. Australian Journal of Crop Science 13: 773-779.

Sublett, W.L., Barickman, T.C., Sams, C.E. 2018. The effect of environment and nutrients on hydroponic lettuce yield, quality, and phytonutrients. Horticulturae 4: 48-63.

Sudré, C.P., Rodrigues, R., Riva, E.M., Karasawa, M., Amaral Júnior, A.T. 2005. Divergência genética entre acessos de pimenta e pimentão utilizando técnicas multivariadas. Horticultura Brasileira 23: 22-27.
Targino, A.J., Oliveira, F.D., Oliveira, M.T., Régis, L.R., Neta, H.M., Cordeiro, C., Alves, F.T., Nascimento, L.V., Pessoa, V.G., Oliveira, A.A., Souza, M.W., Menezes, P.V., Costa, J.P., Marques, I.C., Freitas, R.S. 2019. Lettuce growth in different pot volumes and irrigation frequencies under saline stress. The Journal of Agricultural Science 11: 494503.

Treuren, R., Hintun, T.H. 2009. Comparison of anonymous and targeted molecular markers for the estimation of genetic diversity in ex situ conserved Lactuca. Theoretical and Applied Genetics 119: 1265-1279.

Wiseman, E.M., Dado, S.B., Reifen, R. 2017. The vicious cycle of vitamin a deficiency: A review, Critical Reviews in Food Science and Nutrition 57: 3703-3714.

Conflict of Interest Statement: The authors declare that the research was conducted in the absence of any commercial or financial relationships that could be construed as a potential conflict of interest.

All the contents of this journal, except where otherwise noted, is licensed under a Creative Commons Attribution License attribuition-łype BY. 